\title{
Frequency and Mode Shapes of Au Nanowires Using the Continuous Beam Models
}

\author{
Hayri Metin Numanoglu, Kadir Mercan, Ömer Civalek ${ }^{*}$ \\ Akdeniz University, Civil Engineering Department, \\ Division of Mechanics, Antalya-TURKIYE \\ *E-mail address: civalek@yahoo.com
}

Received date: March 2017

\begin{abstract}
Free vibration analysis of Au nanowires has been investigated. Au nanowire is modeled as a thin beam by using the continuum theory. Three-different cross-sections such as circular, rectangular and triangular are taken into consideration for ultra thin nanowires. Frequency values have been obtained for different geometric parameters and simply supported boundary condition $(S-S)$. This study is helpful for design of the nanowires based instruments in modern Nanoelectromechanical systems (NEMS).
\end{abstract}

Keywords: Nanowires, Au, Frequency, Mode shapes, Mechanical properties.

\section{Introduction}

It is known that the nanowire is one-dimensional nanostructure. Nanowires have many novel and potential applications due to their unique physical properties such as electrical, magnetic, optical, and mechanical. Many of previous theoretical investigations in this area employed molecular dynamic simulations to obtain the mechanical properties [1-7]. Frequency properties are important for some nanowire applications such as actuators, probes, resonators, and sensors. In this study, free vibration analysis of $\mathrm{Au}$ nanowire is investigated. Nanowire is modeled via Euler-Bernoulli beam as mechanical model. The effects of cross-section, mode numbers and dimension on frequency have been discussed.

\section{Discrete singular convolution (DSC)}

The method of discrete singular convolution (DSC) is a novel kind numerical approach for numerical solutions of differential equations [8]. Wei and his co-workers first applied the DSC algorithm to solve solid and fluid mechanics problem [9-18]. Civalek [19-30] gives numerical solution of free vibration problem of rotating and laminated conical shells and plates. Consider a distribution, $T$ and $\eta(t)$ as an element of the space of the test function. A singular convolution can be defined by [9] 


$$
F(t)=(T * \eta)(t)=\int_{-\infty}^{\infty} T(t-x) \eta(x) d x
$$

where $T(t-x)$ is a singular kernel. For example, singular kernels of delta type [10]

$$
T(x)=\delta^{(n)}(x) ; \quad(\mathrm{n}=0,1,2, \ldots,)
$$

Kernel $T(x)=\delta(x)$ is important for interpolation of surfaces and curves, and $T(x)=\delta^{(n)}(x)$ for $n>1$ are essential for numerically solving differential equations. With a sufficiently smooth approximation, it is more effective to consider a discrete singular convolution [11]

$$
F_{\alpha}(t)=\sum_{k} T_{\alpha}\left(t-x_{k}\right) f\left(x_{k}\right)
$$

The Shannon's kernel is regularized as [11]

$$
\delta_{\Delta, \sigma}\left(x-x_{k}\right)=\frac{\sin \left[(\pi / \Delta)\left(x-x_{k}\right)\right]}{(\pi / \Delta)\left(x-x_{k}\right)} \exp \left[-\frac{\left(x-x_{k}\right)^{2}}{2 \sigma^{2}}\right] ; \sigma>0 .
$$

Equation (4) can also be used to provide discrete approximations to the singular convolution kernels of the delta type [12]

$$
f^{(n)}(x) \approx \sum_{k=-M}^{M} \delta_{\Delta}\left(x-x_{k}\right) f\left(x_{k}\right)
$$

\section{Euler-Bernoulli beam model}

Beam model is widely used for nano-scaled components analysis [31-33]. Governing equation of motion for a beam is given as [35]:

$$
E I \frac{\partial^{4} w(x, t)}{\partial x^{4}}+\rho A \frac{\partial^{2} w(x, t)}{\partial t^{2}}=f(x, t)
$$

By using the analytical (separation of variables) and the DSC methods, related equation is solved for three different cross-sections (Table 1) and S-S boundary condition listed in Table 2. The resulting frequency equation can be expressed as follows: 


$$
\omega=\frac{n^{2} \pi^{2}}{L^{2}} \sqrt{\frac{E I}{\rho A}}
$$

\section{Numerical results}

By using the three-different cross sections given in Table 1, frequency values are obtained for S$\mathrm{S}$ nanowires for Au material. The Young modulus of Au used in calculations is $79 \mathrm{GPa}$, and mass density is $\rho=19.3 \mathrm{gr} / \mathrm{cm}^{3}$. Results are depicted in Table 2 and Figs $1-2$, respectively. The results given in Table 2 are obtained via DSC method. The other results are obtained via analytical.

Table 1. Cross-sections, areas and moment of inertia formulas of nanowire

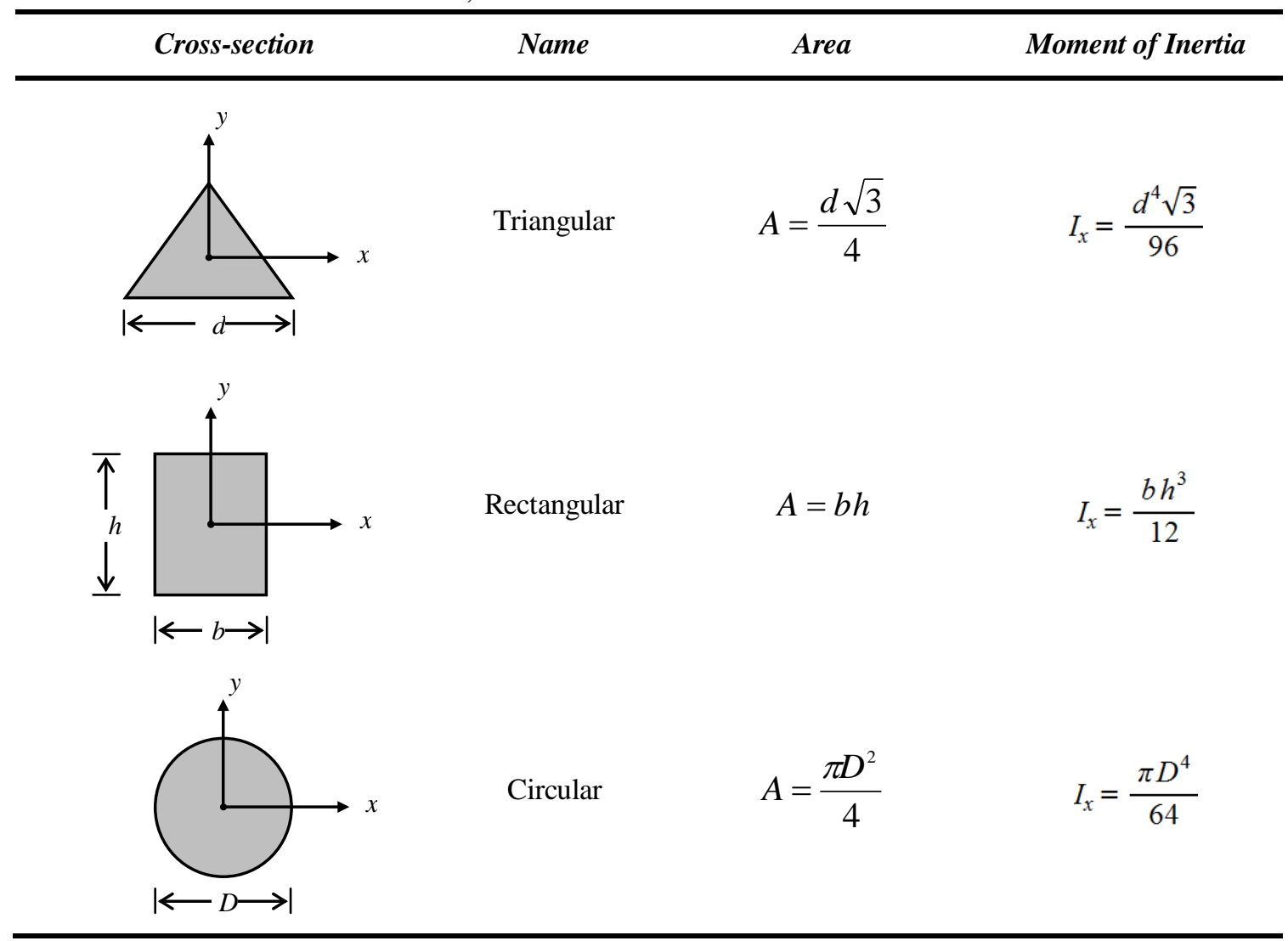

Table 2. Frequency values $(\mathrm{GHz})$ for three-different cross sections

\begin{tabular}{cccc}
\hline & \multicolumn{3}{c}{$A=10 \mathrm{~nm}^{2}, L=50 \mathrm{~nm}$} \\
\cline { 2 - 4 } Mode Numbers & $\begin{array}{c}\text { Circular } \\
D=3.57 \mathrm{~nm}\end{array}$ & $\begin{array}{c}\text { Rectangular } \\
h=5 \mathrm{~nm} \\
b=2 \mathrm{~nm}\end{array}$ & $\begin{array}{c}\text { Triangular } \\
d=4.81 \mathrm{~nm}\end{array}$ \\
\hline 1 & 7.1346 & 11.5345 & 7.8439 \\
2 & 28.5285 & 46.1207 & 31.6972 \\
3 & 64.1647 & 103.7664 & 70.5801 \\
4 & 114.0682 & 184.4720 & 125.4836 \\
5 & 178.2203 & 288.2246 & 196.0677 \\
\hline
\end{tabular}




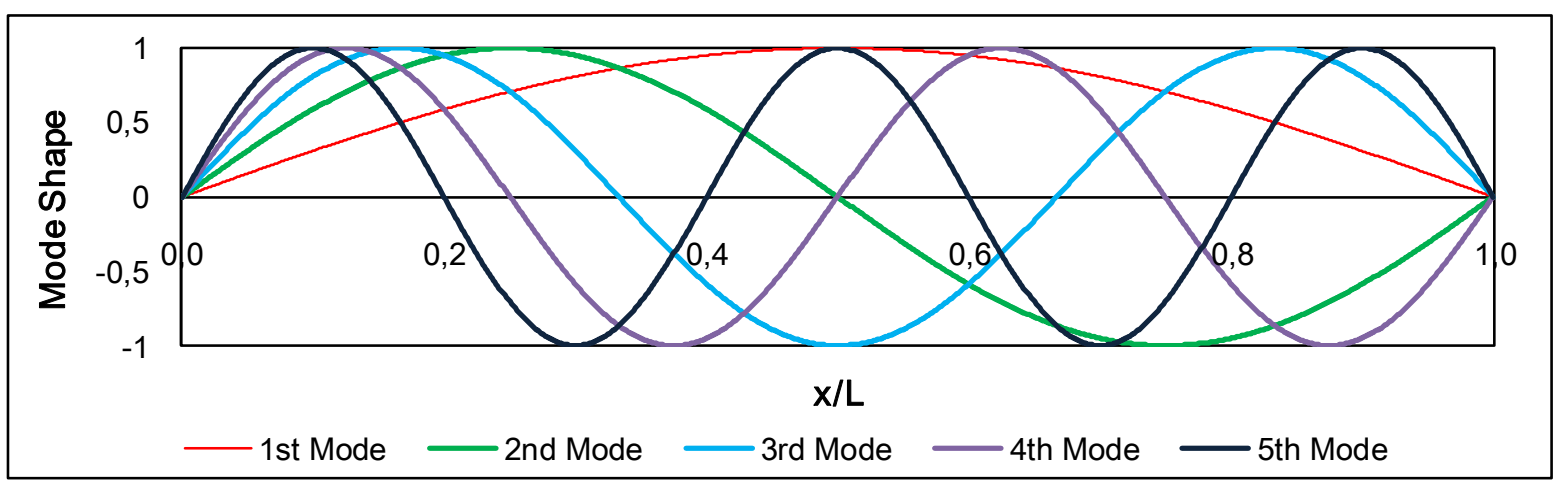

Fig. 1. First five mode shape for both ends are simply supported microbeam.

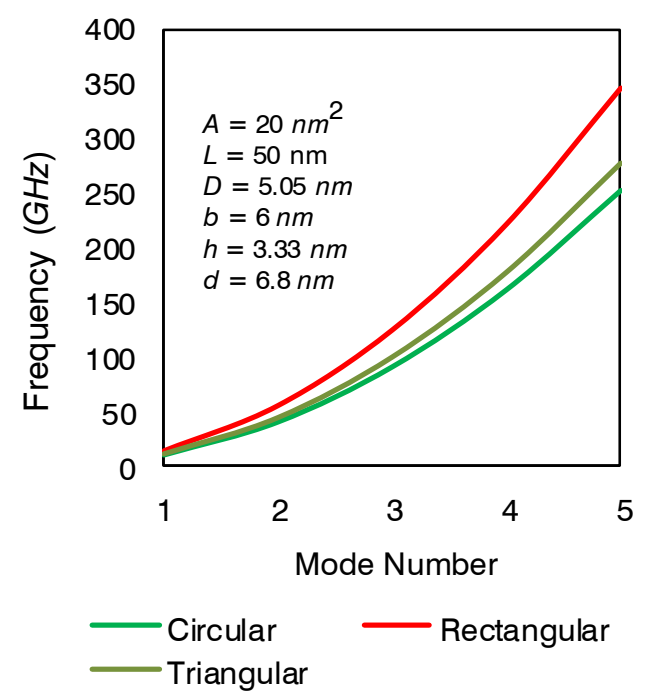

Fig. 2. Natural frequency values for different cross-sections and first five mod numbers

\section{Concluding remarks}

Free vibration analysis of gold nanowire is presented. By using continuum beam theory, the governing equation is obtained for $\mathrm{Au}$ nanowire. Then frequency and mode shapes obtained for different parameters. Frequency values are increased with the increasing value of mode numbers. Rectangular cross-section has biggest frequency value for Au nanowires using same cross-section area. Also, circular nanowire has smaller frequency value than the rectangular and triangular.

\section{Acknowledgements}

The financial support of the Scientific Research Projects Unit of Akdeniz University is gratefully acknowledged. 


\section{References}

[1] Li, Y., Song, J., Fang, B., Zhang, J., Surface effects on the postbuckling of nanowires, J Phys D: Appl Phys, 44, 425304, 2011.

[2] Wang, D., Zhao, J., Hu, S., Yin, X., Liang, S., Liu, Y., Deng, S., Where, and how, does a nanowire break?, Nano Letter, 7, 1208, 2007.

[3] Wang, Z., Zu, X., Gao, F., Weber, W.J., Atomistic simulations of the mechanical properties of silicon carbide nanowires, Phys Rev B, 77, 224113, 2008.

[4] Miller, R.E., Shenoy, V.B., Size-dependent elastic properties of nanosized structural elements, Nanotechnol, 11, 139, 2000.

[5] Kutucu, B., Nanoteknoloji ve Çift Duvarlı Karbon Nanotüplerin İncelenmesi, Yüksek Lisans Tezi, İstanbul Teknik Üniversitesi, Fen Bilimleri Enstitüsü, 2010.

[6] Uzun, B., Karbon Nanotüplerin Kiriş Modeli ve Titreşim Hesabı, Lisans Tezi, Akdeniz Üniversitesi, 2016.

[7] Yetim, A., Karbon Nanotüpler, Yüksek Lisans Tezi, Çukurova Üniversitesi, 2011.

[8] Wei, G.W., Discrete singular convolution for the solution of the Fokker-Planck equations. $J$ Chem Phys, 110, 8930-8942, 1999.

[9] Wei, G.W., Solving quantum eigenvalue problems by discrete singular convolution, $J$ Phys B: At Mol Opt Phys, 33, 343-352, 2000.

[10]Wei, G.W., Discrete singular convolution for the Sine-Gordon equation, Physica D, 137, 247259, 2000.

[11]Wei, G.W., A unified approach for the solution of the Fokker-Planck equation, J Phys A:Math Gen, 33, 4935-4953, 2000.

[12]Wei, G.W., Wavelets generated by using discrete singular convolution kernels, J Phys A:Math Gen., 33, 8577-8596, 2000.

[13] Wei, G.W., Zhang, D.S., Althorpe, S.C., Kouri, D.J., Hoffman, D.K., Wavelet-distributed approximating functional method for solving the Navier-Stokes equation, Comp Physics Commun, 115, 18-24, 1998.

[14]Wei, G.W., Kouri, D.J., Hoffman, D.K., Wavelets and distributed approximating functionals, Comp Physics Commun, 112, 1-6, 1998.

[15]Zhao, S., Wei, G.W., Xiang, Y., DSC analysis of free-edged beams by an iteratively matched boundary method, J Sound Vibr, 284, 487-493, 2005.

[16]Hou, Z.J., Wei, G.W., A new approach to edge detection, Pattern Recognit, 35, 1559-1570, 2002. 
[17] Lim, C.W., Li, Z.R., Xiang, Y., Wei, G.W., Wang, C.M., On the missing modes when using the exact frequency relationship between Kirchhoff and Mindlin plates, Adv Vib Eng, 4, 221-248, 2005.

[18] Lim, C.W., Li, Z.R., Wei, G.W., DSC-Ritz method for high-mode frequency analysis of thick shallow shells, Int J Num Methods Eng, 62, 205-232, 2005.

[19] Civalek, Ö., An efficient method for free vibration analysis of rotating truncated conical shells, Int J Press Vessels Pip, 83, 1-12, 2006.

[20]Civalek, Ö., Three-dimensional vibration, buckling and bending analyses of thick rectangular plates based on discrete singular convolution method, Int J Mech Sci, 49, 752-765, 2007.

[21]Civalek, Ö., Nonlinear analysis of thin rectangular plates on Winkler-Pasternak elastic foundations by DSC-HDQ methods, Appl Math Model, 31, 606-624, 2007.

[22]Civalek, Ö., Free vibration analysis of composite conical shells using the discrete singular convolution algorithm, Steel Compos Struct, 6(4), 353-366, 2006.

[23]Civalek, Ö., Numerical analysis of free vibrations of laminated composite conical and cylindrical shells: discrete singular convolution (DSC) approach, J Comp Appl Math, 205, 251-271, 2007.

[24]Civalek, Ö., Korkmaz, A.,Ç Demir, Ç., Discrete singular convolution approach for buckling analysis of rectangular Kirchhoff plates subjected to compressive loads on two-opposite edges Adv Eng Softw, 41, 557-560, 2010.

[25]Gürses, M., Akgöz, B., Civalek, Ö., Mathematical modeling of vibration problem of nano-sized annular sector plates using the nonlocal continuum theory via eight-node discrete singular convolution transformation, Appl Math Comput, 219, 3226-3240, 2012.

[26]Gürses, M., Civalek, Ö., Korkmaz, A.K., Ersoy, H., Free vibration analysis of symmetric laminated skew plates by discrete singular convolution technique based on first-order shear deformation theory. Int J Numer Method Eng, 79, 290-313, 2009.

[27]Civalek, Ö., Nonlinear dynamic response of laminated plates resting on nonlinear elastic foundations by the discrete singular convolution-differential quadrature coupled approaches,

Compos Part B: Eng, 50, 171-179, 2013.

[28]Civalek, Ö., Diferansiyel Quadrature Metodu ile Elastik Çubukların Statik, Dinamik Ve Burkulma Analizi, XVI Mühendislik Teknik Kongresi, Kasım, ODTÜ, Ankara, 2001.

[29]Civalek, Ö., Ülker, M., HDQ-FD integrated methodology for nonlinear static and dynamic response of doubly curved shallow shells, Struct Eng Mech, 19(5), 535-550, 2005.

[30]Civalek, Ö., Nöro-Fuzzy Tekniği ile Dikdörtgen Plakların Analizi, III. Ulusal Hesaplamalı Mekanik Konferans1, 1998. 
[31]Mercan, K., Civalek, Ö., Buckling Analysis of Silicon Carbide Nanotubes (SiCNTs), Int J Eng Appl Sci, 8 (2), 101-108, 2016.

[32]Demir, Ç., Civalek, Ö., Nonlocal Finite Element Formulation for Vibration, Int J Eng Appl Sci, 8(2), 109-117, 2016.

[33]Demir, Ç., Civalek, Ö., Nonlocal deflection of microtubules under point load, Int J Eng Appl Sci, 7(3), 33-39, 2015.

[34]Akgöz, B., Civalek, Ö., Analysis of microtubules based on strain gradient elasticity and modified couple stress theories, Adv Vib Eng, 11(4), 385-400, 2012.

[35] Rao S.S., Vibration of Continuous Systems, John Wiley \& Sons, 2007. 